GENTILE NEW YORK 



\section{GENTILE NEW YORK}

The Images of Non-Jews

among Jewish Immigrants

G I L R I B A K

RUTGERS UNIVERSITY PRESS

New Brunswick, New Jersey, and London 
Library of Congress Cataloging-in-Publication Data

Ribak, Gil.

Gentile New York : the images of non-Jews among Jewish immigrants / Gil Ribak. p. $\mathrm{cm}$.

Includes bibliographical references and index. ISBN 978-0-8135-5164-7 (hardcover : alk. paper)

I. Jews-New York (State)—New York-Attitudes. 2. Gentiles_Public opinion.

3. Public opinion-New York (State)—New York. 4. Immigrants-New York (State) New York-Attitudes. 5. Jews-New York (State)—New York-History-Igth century. 6. Jews-New York (State)—New York-History—2oth century. 7. New York (N.Y.)Ethnic relations. I. Title. II. Title: Images of non-Jews among Jewish immigrants. FI28.9.J5R44 2012 $305.8009747-\mathrm{dc} 22$

2011010860

A British Cataloging-in-Publication record for this book is available from the British Library.

Copyright (C) 2012 by Gil Ribak

All rights reserved

No part of this book may be reproduced or utilized in any form or by any means, electronic or mechanical, or by any information storage and retrieval system, without written permission from the publisher. Please contact Rutgers University Press, Ioo Joyce Kilmer Avenue, Piscataway, NJ 08854-8099. The only exception to this prohibition is "fair use" as defined by U.S. copyright law.

Visit our Web site: http:// rutgerspress.rutgers.edu

Manufactured in the United States of America 
To my parents Eliezer of blessed memory and Bruria, may she be set apart for long life 
